\title{
A Comparative Study on Implementation of Vocational Education Policies in Beijing and Manila
}

\author{
Xinqin Zhang \\ Graduate School, Centro Escolar University, Manila 1005, Philippines; \\ Economics and Management School, Huanghuai University, Zhumadian 463000, China. \\ xinqinzhangceu@yahoo.com
}

Keywords: Technical and vocational education and training (TVET), implementation, vocational education policy, enhancement.

\begin{abstract}
The focus of the study is to determine Technical and Vocational Education and Training (TVET) policies in Beijing and the Manila and their implementation of TVET programs and to seek and recommend solutions to existing problems. The researcher surveyed 283 respondents in the two places. Descriptive research method was utilized to assess the implementation of TVET policies and programs. Based on the result of the study, the researcher found out that the status of implementation of TVET programs in Beijing and Manila is good in general. However, for Beijing, the government support on private TVET schools is not enough. Beijing municipal government needs to strengthen and support the construction of private TVET schools. For Manila, budget allocated for public TVET schools is insufficient. Manila municipal government needs give more financial support and build more public TVET schools for TVET development. It is essential to enhance the cooperation among TVET institutions.
\end{abstract}

\section{Introduction}

Vocational education is an essential component of modern education. The development of vocational education needs the support and guidance of vocational education policy. In order to promote the development of vocational education, the Chinese and Philippine governments both have enacted laws and established the management institutions.

Ministry of Education (MOE) of People's Republic of China (PRC) (1996) released the first specialized law: Vocational Education Law of the People's Republic of China. From then, vocational education began to enter the legalized health development track. According to the law, the MOE of the PRC is in charge of China's TVET. There is a Department of Vocational \& Adult Education (DVAE) under the MOE, which is affiliated to the MOE of PRC. Its function is in charge of specific management affairs of vocational education [1].

Since the reform and opening, the development of vocational education reform in China has made great achievements. The basic policies and system are admittedly far from perfect; thus, the degree earned for intended global competitiveness is not resilient to meet the demands of international standards. China's vocational education policies and systems cannot adapt to speeding up the transformation of economic development requirements [2].

Republic of the Philippines (1994) created The Technical Education and Skills Development Authority (TESDA) through Republic act NO. 7796. Technical Vocational Education and Training (TVET) is in charge of TESDA in the Philippines [3]. The cost-benefit ratio is an important key factor in the assessment to bestow technical and vocational education and trainings that are more directly aligned with the demands of the labor market and would likewise satisfy the growing needs to provide employment for the people whether for local or international service.

A phenomenon of mismatch between graduates and labor market needs exists in the Philippines. According to researchers of the Philippine Social Science Council, finding revealed weak linkages between education and employment. Studies showed no strong relevance between educational attainments, employment levels and salary rates. The Philippine government should pursue to 
develop the full potential of the people. Technical Education and Skills Development Authority (TESDA) and Commission on Higher Education (CHED) should endeavor to cooperate with each other. Department of Labor \& Employment (DOLE) and Department of Trade and Industry (DTI) should keep in line with TESDA and CHED [4].

Alfred, et al.(2012) assessed the implementation of the Strengthened Technical and Vocational Education Program - Competency Based Curriculum (STVEP-CBC) in Region X.- Northern Mindanao and suggested that regular monitoring should be strengthened to keep track in the effective and efficient implementation of the program[5]. Osmania. (2013) examined the implementation of technical education programs in Rivers State, Nigeria and recommended that only professionally qualified technical and science teachers be recruited into the system [6]. Through empirical survey, Liu, et al. (2015) found China's vocational education policies have not been well implemented. The vocational colleges and enterprises and other industry stakeholders should deeply participate in making vocational education policy, create a social atmosphere to pay attention to vocational education, and strengthen propaganda of the implementation of occupation education policy [7]. This study attempted to seek the existing problems in the process of vocational education policy implementation and gave recommendations to enhance future TVET programs in Beijing and Manila.

\section{Methods}

Descriptive research method was used to assess the implementation of TVET policies and programs in China and the Philippines. The researcher used Beijing and Manila's implementation as subjects for survey, being their respective capitals. The researcher divided TVET schools into three types (large, medium, small) based on enrollment data in 2017. The researcher chose 2 public and 3 private TVET schools (Higher Vocational College) in Beijing, and 2 SUC (State Universities and College) and 3 HEIs (Higher Education Institutions) in Manila. The researcher selected 283 TVET administrators and teachers according to Slovene's formula in Beijing and 33 TVET administrators and trainers in Manila as respondents.

In order to validate the research instrument, the researcher submitted the questionnaires to the experts in the field to get feedback and recommendations for the improvement of the instrument. The suggestions and recommendations of the experts were integrated in the final draft. Before the survey began, the questionnaires were pre-tested. Pre-testing in the study involved the following phases: questionnaire validity and questionnaire reliability. Descriptive and inferential statistics were used in this study. The following statistical treatments were used for data reduction: standard deviation, Mean Score, Likert Scale and T-test. T-test is used for comparisons of respondents from Beijing and Manila regarding the implementation of TVET policies and programs.

\section{Results}

From the gathered data, the following comparisons results of the evaluation of the TVET Schools respondents regarding on the implementation of TVET policies and programs were gained:

Table 1. Beijing Public and Private TVET Schools Respondents

\begin{tabular}{ccccccc}
\hline \multicolumn{1}{c}{ Variables } & Type of Schools & Mean & S.D. & t-value & p-value & Sig \\
\hline \multirow{2}{*}{ Program Personnel } & Beijing Public & 3.790 & .6709 & 4.444 & $\mathrm{P}=0.000<0.01$ & VS \\
& Beijing Private & 3.508 & .3816 & & & \\
Budget Allocation & Beijing Public & 3.38 & .353 & 7.050 & $\mathrm{P}=0.000<0.01$ & VS \\
& Beijing Private & 3.11 & .286 & & & \\
Program Curriculum & Beijing Public & 3.28 & .399 & 2.172 & $\mathrm{P}=0.031<0.05$ & $\mathrm{~S}$ \\
& Beijing Private & 3.10 & .450 & & & \\
Training Materials & Beijing Public & 3.6473 & .46561 & -.423 & $\mathrm{P}=0.673>0.05$ & NS \\
& Beijing Private & 3.6693 & .39351 & & & \\
\multirow{2}{*}{ Physical Facilities } & Beijing Public & 3.806 & .4712 & 5.001 & $\mathrm{P}=0.000<0.01$ & $\mathrm{VS}$ \\
& Beijing Private & 3.545 & .3936 & & & \\
\hline
\end{tabular}


Table 1 shows that there is no significant difference between Beijing public and private TVET School respondents' assessment on its implementation of TVET policies in term of training material with the p-value of 0.673 which is more than the 0.05 level of significance. There is a significant difference between Beijing public and private TVET School respondents' assessment on its implementation of TVET policies in term of program curriculum in general with the p-value of 0.031 which is more than the 0.01level of significance and less than the 0.05 level of significance. There is a very significant difference between Beijing public and private TVET School respondents' assessment in its implementation of TVET policies in terms of program personnel, budget allocated and physical facilities with the p-value of 0.000 which is less than the 0.01 level of significance.

Table 2. Manila Public and Private TVET Schools Respondents

\begin{tabular}{ccccccc}
\hline Variables & Type of Schools & Mean & S.D. & t-value & p-value & Sig \\
\hline Program & Manila Public & 3.750 & .4031 & -.218 & 0.829 & NS \\
personnel & Manila Private & 3.784 & .4316 & & & \\
Budget & Manila Public & 2.65 & .362 & -4.406 & 0.000 & VS \\
Allocation & Manila Private & 3.22 & .343 & & & \\
Program & Manila Public & 3.64 & .424 & -.179 & 0.859 & NS \\
Curriculum & Manila Private & 3.67 & .553 & & & \\
Training & Manila Public & 3.5455 & .30814 & -1.035 & 0.309 & NS \\
Materials & Manila Private & 3.6818 & .37765 & & & \\
Physical & Manila Public & 2.886 & .4237 & -3.293 & 0.002 & VS \\
Facilities & Manila Private & 3.489 & .5260 & & & \\
\hline
\end{tabular}

Table 2 shows that there is no significant difference between Beijing public and private TVET School respondents' assessment on implement of TVET policies in terms of program personnel, program curriculum and training materials with the p-value of 0.829,0.859 and 0.309 respectively, which are more than the 0.05 level of significance. There is a very significant difference between Beijing public and private TVET school respondents' assessment on their implementation of TVET policies in terms of budget allocated and physical facilities with the p-value of 0.000 which are less than the 0.01 level of significance.

Table 3. Beijing and Manila Public TVET School Respondents

\begin{tabular}{ccccccc}
\hline Variables & Type ofSchools & Mean & S.D. & t-value & p-value & Sig \\
\hline Program Personnel & Public Beijing & 3.791 & .6731 & .305 & 0.765 & NS \\
& Public Manila & 3.750 & .4031 & & & \\
Budget & Public Beijing & 3.38 & .354 & 6.551 & 0.000 & VS \\
Allocation & Public Manila & 2.65 & .362 & & & \\
Program & Public Beijing & 3.28 & .396 & -2.853 & 0.005 & VS \\
Curriculum & Public Manila & 3.64 & .424 & & & \\
Training & Public Beijing & 3.6515 & .46417 & .745 & 0.45 & NS \\
Materials & Public Manila & 3.5455 & .30814 & & & \\
Physical & Public Beijing & 3.812 & .4682 & 6.368 & 0.000 & VS \\
Facilities & Public Manila & 2.886 & .4237 & & & \\
\hline
\end{tabular}

Table 3 shows that there is no significant difference between Beijing and Manila public TVET school respondents' assessment in terms of program personnel with the p-value of 0.765 and training materials with the p-value of 0.45 , which are more than the 0.05 level of significance. However, there is a very significant difference between Beijing and Manila public TVET school respondents' assessment in terms of budget allocated with the p-value of 0.000 , program curriculum with the p-value of 0.005 and physical facilities with the p-value of 0.000 , which are less than the 0.01 level of significance.

Table 4 shows that there is no significant difference between Beijing and Manila private TVET school respondents' assessment in terms of budget allocated with the p-value of 0.101 , training materials with the p-value of 0.890 , physical facilities with the p-value of 0.558 , which are more than the 0.05 level of significance. However, there is a very significant difference between Beijing and Manila private TVET school respondents' assessment in terms of program personnel with the p-value 
of 0.002 and program curriculum with the p-value of 0.001 , which are less than the 0.01 level of significance.

Table 4. Beijing and Manila TVET School Respondents

\begin{tabular}{ccccccc}
\hline Variables & Type of Schools & Mean & S.D. & t-value & p-value & Sig \\
\hline \multirow{2}{*}{ Program Personnel } & Private Beijing & 3.5078 & .38159 & -3.077 & 0.002 & VS \\
& Private Manila & 3.7841 & .43160 & & & \\
\multirow{2}{*}{ Budget Allocated } & Private Beijing & 3.10720 & .28619645 & -1.653 & 0.101 & NS \\
& Private Manila & 3.21969 & .34310084 & & & \\
\multirow{2}{*}{ Program Curriculum } & Private Beijing & 3.1836 & .30976 & -4.022 & 0.001 & VS \\
& Private Manila & 3.6705 & .55306 & & & \\
\multirow{2}{*}{ Training Materials } & Private Beijing & 3.6693 & .39351 & -.139 & 0.890 & NS \\
& Private Manila & 3.6818 & .37765 & & & \\
Physical Facilities & Private Beijing & 3.5449 & .39364 & .588 & 0.558 & NS \\
& Private Manila & 3.4886 & .52598 & & & \\
\hline
\end{tabular}

\section{Discussions}

Based on the results of the study, the researcher came up with the following conclusions:

1. The effectiveness of the implementation of TVET policy in Beijing and Manila TVET schools is good in general.

2. Budget allocation for TVET programs in Beijing is more sufficient than in Manila.

3. Beijing municipal government provides strong support on public TVET schools. Due to enrollment decrease, there is shortage of funds in private TVET schools in Beijing. Meanwhile, budget allocation for TVET schools in Manila is insufficient. Due to shortage of funds, the equipment and the software updating are lagging behind in Manila's public TVET schools.

Base on the results and conclusions, the followings are hereby recommended:

Beijing municipal government needs to strengthen and support the construction of private TVET schools. The following measures are being proposed:

Firstly, the government should encourage social forces to donate money and invest in TVET schools and give more preferential tax policies to run private TVET schools.

Secondly, it is necessary to urge all levels of government and education departments to implement the equal legal status between private schools' students and teachers and public schools' students and teachers according to the law and to eliminate discrimination against private TVET schools. In particular, teachers in private TVET schools should have the same rights as public school teachers in terms of qualification, job evaluation, training and recognition.

Finally, the government should optimize the public finance support policies for private TVET schools, and provide special funds and incentives to support the development of private TVET schools.

Manila municipal can take the following measures to promote TVET development:

Firstly, it is necessary to further improve General Appropriations Act (GAA) and make the allocation of funds at all level be more balanced in the GAA according to certain criteria.

Secondly, the government should raise more funds for TVET development to give more financial support and build more public TVET schools. There are more people who are willing to receive TVET, but the teaching conditions are limited in public TVET schools. They can't accommodate more students.

Thirdly, the government should enhance the cooperation of the public and private TVET schools. Private TVET schools can provide better teaching conditions and practical training equipment, and higher teaching quality. Private TVET schools can provide free accommodation for the registered students in public TVET schools and guide the teachers teaching in public TVET schools. 


\section{Summary}

The Chinese government put forward the initiative "the Silk Road Economic Belt and the 21st-Century Maritime Silk Road” (the Belt and Road Initiative) in 2013.The Philippines can seek more opportunities to be brought to its TVET development. Beijing and Manila municipal governments should strengthen exchanges and cooperation in its respective implementation of vocational education as well as learn from their strengths and weaknesses.

\section{References}

[1]. Ministry of Education of the People's Republic of China, Vocational Education Law of the People's Republic of China,pp.1-2,1996.

[2]. Dong Jian, Research on the public policy of vocation education in China, M.A. Thesis, Dongle University of Finance and Economics, Changchun, China,pp1-3,2016.

[3]. Republic of the Philippines, Technical education and skills development act of 1994 (Republic act no. 7796), pp. 1-2, 1994.

[4]. Sliven, P. (2016). The Continuing Mismatch Between Graduates and Labor Market Needs, A Point of Awareness. The Philippine Star. Retrieve from http://www.philstar.com/

[5]. Alfred, R. C., \& Palms, N. D, Implementation of Strengthened Technical Vocational Education Program-Competency Based Curriculum, Northern Mindanao, and Philippines. JPAIR Multidisciplinary Journey, vol.7, pp. 186-197, 2012.

[6]. Osama, I, Formulation and Implementation of Technical Education Policies in Rivers State, Nigeria, International Journal of Humanities and Social Science Invention, vol.2,pp 24-29,2013.

[7]. Liu, X.X, Dong, R. Z, \& Chen, S.G, Vocational education policy implementation survey report in China, Vocational \& Technical Education Forum, vol.34,pp65-70,2015. 